\title{
PERBANDINGAN ASPEK ONTOLOGI DAN EPISTEMOLOGI ILM AL-MA'ANIY DAN PRAGMATIK
}

\author{
Moch Sony Fauzi
}

Email: inosfa@yahoo.com

Fakultas Humaniora dan Budaya Universitas Islam Negeri Maulana Malik Ibrahim Malang Alamat Korepondensi: Jalan Gajayana 50 Malang, Telp/Fax (0341) 558916

\begin{abstract}
The Ma'aniy and Pragmatics are two field of study that is closely related to language. Both of them have different background. The Ma'aniy was born from the intention to discover the miracle of Qur'an from its language. On the other hand, pragmatics was born from the study of language phenomena in the forms of human utterances. The ma'aniy was born in eastern world, and pragmatics was from the west. Through contrastive analytic and conventional text study this paper is aimed at comparing the epistemological aspects of those two field of study, especially at three different aspects of pragmatics, theory of speech act, implicature and relevance. Those three aspects are found out the similarities with the aspects in ma'aniy. The findings are first, ontologically, there is similarity between ma'aniy and pragmatics, especially in discussing the forms and meaning of speech that is influenced by speech context. Many definitions of those two field of studies have similarities. Second, epistemologically, those two field of studies have similarities, for example, in ma'aniy there is "kalam khabariy" and "kalam insya'iy", that is similar to the maxim violation in the speech implicature in pragmatics.
\end{abstract}

\section{Keywords}

Ilm al-Ma'aniy, Pragmatik, Epistemologi

\section{Pendahuluan}

Pragmatik dan Ilmu al-Ma'aniy adalah dua ilmu yang terkait dengan bahasa, dua ilmu tersebut memiliki latar belakang kemunculan dan dari kawasan yang berbeda. Ilmu al-Ma'aniy lahir dari keinginan menguak rahasia I'jaz al-Quran dari sisi ketinggian nilai bahasanya, sedangkan Pragmatik lahir dari kajian terhadap fenomena kebahasaan yang berbentuk ujaran-ujaran yang muncul dalam percakapan manusia sehari-hari. Ilmu al-Ma'aniy lahir di belahan dunia timur, sedangkan Pragmatik lahir di Barat. Namun demikian hal ini bukanlah sesuatu yang harus diperdebatkan karena memang ilmu bersifat universal dan tidak dibatasi oleh ruang dan waktu.

Dalam kajian linguistik modern dikenal dua kelompok besar, yaitu linguistik mikro dan linguistik makro, linguistik mikro mengkaji unsurunsur bahasa yang tidak dipengaruhi konteks (Fonologi, Morfologi, Sintaksis, dan semantik), sedangkan linguistik makro mengkaji fenomena kebahasaan yang dipengaruhi oleh konteks (Pragmatik, Analisis Wacana, Sosiolinguistik, dan Etnolinguistik) (Kadarisman, 2010:3).
Pragmatik menurut Prucha, sebagaimana dikutip oleh Yan Huang, merupakan teori-teori komunikasi linguistik yang meliputi cara-cara mempengaruhi orang lain dengan komunikasi verbal (Huang, 2007:4), sedangkan menurut Levinson (1992), pragmatik dipahami sebagai studi tentang hubungan antara bahasa dan konteksnya yang merupakan dasar dari penentuan pemahamannya. Sependapat dengan Levinson, Leech (1983:13-15) berpendapat, bahwa pragmatik adalah studi mengenai makna dalam hubungannya dengan situasi-situasi ujar yang meliputi : penyapa dan pesapa, konteks sebuah tuturan, tujuan sebuah tuturan. 


\section{Penutup}

Berdasarkan analisa data di atas maka penulis memberikan kesimpulan sebagai berikut. Pertama, secara ontologik antara ilmu al-ma'aniy dan pragmatik terdapat kesamaan, terutama dalam mengkaji bentuk dan makna tuturan yang dipengaruhi oleh situasi tuturan (konteks), berbagai definisi tentang kedua ilmu ini memiliki kemiripan. Kedua, secara epistemologik, kedua ilmu ini memiliki kesamaan, berbagai teori yang berhasil dibangun melalui dua ilmu ini dalam beberapa aspek terdapat ketersinggungan, sebagai contoh dalam kajian ilmu al-Ma'aniy tentang kalam khabariy dan kalam insya'iy di dalamnya terdapat kajian yang mirip dengan kajian tentang pelanggaran maksim dalam implikatur percakapan yang terdapat dalam kajian pragmatik. 


\section{DAFTAR PUSTAKA}

Al-Hasyimiy, Ahmad. 1960. Jawaahiir al-Balaaghah. Indonesia: Daar ihya al-Uluum.

Arikunto, Suharsimi. 1998. Prosedur Penelitian: Suatu Pendekatan Praktek. Jakarta: Rineka Cipta.

Austin, John L. 1962. How to do Things with Words. Oxford: Oxford University Press.

Bogdan, Robert C. and Biklen, dalam Ahmad Shonhaji. 2003. Bahan-Bahan Kuliah Metode Penelitian. Malang: Program Pascasarjana-Universitas Islam Malang.

Grice, H. Paul. 1957. 'Logic and Conversation' dalam P.Cole dan J.Morgan (eds). Syntax and Semantics 3: Speech Acts. New York: Academic Press.

Leech, Geoffrey. 1983. Principles of Pregmatics. New York: Longman Linguistics Library.

Levinson, Stephen C. 1992. Pragmatics. Cambridge: Cambridge University Press.

Rahardjo, Mudjia. 2010. Bahan-bahan Kuliah Metode Penelitian. Program Pascasarjana UIN Maulana Malik Ibrahim Malang

Shaleh, A.Q.A, dan Kulaib. 1410 H. Ilm alMa'aniy. Riyadh: Idaarah al-Tathwiir al-Khuthath wa al-Manaahij Jaami'ah al-Imam Muhammad Ibnu Saud Al-Islamiyyah.

Sperber, dan Deirde Wilson. 1991. Inference and Implicature, dalam S.Davis (ed). Pragmatics: A Reader, New York: Oxford University Press.

Sumarmo, Marmo. 1987. Pragmatik dan Perkembangan Mutakhirnya. Makalah disajikan dalam pertemuan linguistic Lembaga Bahasa Atma Jaya Universitas Katolik Atma Jaya. Jakarta, 1-2 September.

Tim Pengembangan Penelitian. 1993. Pedoman Penelitian. Malang: IKIP Malang 